\title{
The origins and persistence of Homo floresiensis on Flores: biogeographical and ecological perspectives
}

Robin W. Dennell, Department of Archaeology, University of Sheffield, Northgate House, West Street, Sheffield, S1 4ET, UK. r.dennell@sheffield.ac.uk

Julien Louys, School of Earth Sciences, The University of Queensland, St. Lucia, QLD 4072, Australia. E-mail: j.louys@uq.edu.au

Hannah J. O’Regan, Department of Archaeology, Humanities Building, University Park, University of Nottingham, Nottingham, NG7 2RD, UK. Tel: 0115951 4843. E-mail:

Hannah.O’Regan@Nottingham.ac.uk

David M. Wilkinson, School of Natural Sciences and Psychology, Liverpool John Moores University, Byrom Street, Liverpool, L3 3AF, UK. Tel: E-mail: D.M.Wilkinson@ljmu.ac.uk

\begin{abstract}
The finding of archaeological evidence predating $1 \mathrm{Ma}$ and a small hominin species (Homo floresiensis) on Flores, Indonesia, has stimulated much research on its origins and ancestry. Here we take a different approach and examine two key questions -1 ) how did the ancestors of $H$. floresiensis reach Flores and 2) what are the prospects and difficulties of estimating the likelihood of hominin persistence for over 1 million years on a small island? With regard to the first question, on the basis of the biogeography we conclude that the mammalian, avian, and reptilian fauna on Flores arrived from a number of sources including Java, Sulawesi and Sahul. Many of the terrestrial taxa were able to float or swim (e.g. stegodons, giant tortoises and the Komodo dragon), while the rodents and hominins probably accidentally rafted from Sulawesi, following the prevailing currents. The precise route by which hominins arrived on Flores cannot at present be determined, although a route from South Asia through Indochina, Sulawesi and hence Flores is tentatively supported on the basis of zoogeography. With regards to the second question, we find the archaeological record equivocal. A basic energetics model shows that a greater number of small-bodied hominins could persist on Flores than larger-bodied hominins (whether $\mathrm{H}$. floresiensis is a dwarfed species or a descendent of an early small-bodied ancestor is immaterial here), which may in part explain their apparent long-term success. Yet the frequent tsunamis and volcanic eruptions in the region would certainly have affected all the taxa on the island, and at least one turnover event is recorded, when Stegodon sondaari became extinct. The question of the likelihood of persistence may be unanswerable until we know much more about the biology of $H$. floresiensis.
\end{abstract}




\section{Introduction}

The island of Flores, Indonesia, has been the source of three of the least expected and most significant discoveries in palaeoanthropology in the last 50 years. The first and best known discovery was that of $H$. floresiensis, ("the hobbit,") found in a late Pleistocene context at the cave of Liang Bua (Figure 1.; Brown et al., 2004; Morwood et al., 2004) and associated with a simple core and flake assemblage that extended back to ca. 95 ka (Moore et al., 2009; Roberts et al., 2009). Despite concerns that the small brain size of $H$. floresiensis of only ca. $400 \mathrm{cc}^{3}$ (or roughly the same as a chimpanzee's) precluded it from being the maker of these tools, the absence of any evidence of $H$. sapiens on the island until the Holocene makes it the only likely candidate. The second and third major discoveries on Flores were that hominins had been present long before the Late Pleistocene: at Mata Menge and Boa Lesa, stone artefacts were found associated with the remains of the largebodied stegodon Stegodon florensis florensis, dated by fission track to $0.88 \pm 0.07 \mathrm{Ma}$ (Morwood et al.,1998), and at Wolo Sege, artefacts associated with pygmy Stegodon sondaari were dated by

${ }^{40} \mathrm{Ar} /{ }^{39} \mathrm{Ar}$ to a minimum age of $1.02 \pm 0.02 \mathrm{Ma}$ (Brumm et al., 2010). Flores is thus a unique example of an island that was never joined to a continental shelf during low sea levels but was nevertheless colonised by hominins before the late Pleistocene.

<insert Fig 1 near here>

Discussion over the Liang Bua finds has largely focussed on the question of who were the ancestors of $H$. floresiensis? Or, put another way, how does $H$. floresiensis fit into the overall picture of human evolution? Three views quickly emerged over its possible ancestry: i) that it was a pathological or pygmy population of $H$. sapiens (Hershkovitz et al., 2007; Jacob et al., 2006; Perry and Dominy, 2009; Richards, 2006); ii) that it was a dwarfed population descended from the type of $H$. erectus s.s. populations seen on neighbouring Java (Kaifu and Fujita, 2012); and iii) most contentious of all is the suggestion that it belonged to a primitive lineage that extended back to early forms of Homo or even Australopithecus that dispersed from Africa in the earliest part of the Pleistocene (Aiello, 2010; Argue et al., 2006; Brown and Maeda, 2009; Falk et al., 2009; Jungers et al., 2009; Larson et al., 2009; Morwood and Jungers, 2009; Tocheri et al., 2007). Although most researchers now agree that the Liang Bua hominins were not pathological or pygmy Homo sapiens, opinion is still divided between those favouring a local population of $H$. erectus or a distant and earlier lineage as its ancestors. Until we know the type (and size) of hominin that made the artefacts at Mata Menge and Wolo Sege, any discussion about the phylogenetic history of $H$. floresiensis is likely to remain inconclusive. 
Here we take a biogeographical and ecological approach to the archaeology and consider two specific questions: 1 ) where was the likely source population for $\mathrm{H}$. floresiensis; and 2 ) what are the prospects and difficulties of estimating the likelihood of its persistence on Flores for over $\sim 1 \mathrm{Ma}$ ?

\section{Source Populations}

\subsection{Arrival on Flores}

The question of how H. floresiensis - or its predecessors - arrived on Flores is an important one because Flores would always have been an island that was at least $19 \mathrm{~km}$ from other islands on the Sunda Shelf, even when sea levels were over 100m lower than today (Morwood et al., 1998; Morwood and Jungers, 2009). As land connections with neighbouring islands such as Bali, Lombok and Java can be excluded, it had to arrive by sea. Only two options seem plausible. The first assumes that the first to reach Flores was H. erectus, and that it was already capable by 840 ka (the age of Mata Menge) of using watercraft for repeated sea journeys (Morwood et al., 1998; O'Sullivan et al., 1998; Morwood, 2001; Bednarik, 1999). (The same line of reasoning presumably applies to the inhabitants of Wolo Sege a million years ago.) The idea that $H$. erectus might have used watercraft was enthusiastically pursued by Bednarik (2003), who demonstrated that a sea-going boat or raft could be made by using the same type of early Palaeolithic tools found on many Middle Pleistocene sites. Indeed, one of the rafts that he built with a simple lithic technology sailed $1000 \mathrm{~km}$ from Timor to Australia (Nale Tasih, 1, with a crew of five). Another sailed $90 \mathrm{~km}$ from Bali to Lombok (Nale Tasih 4, with a crew of 12), although the Lombok Strait crossing appears to have been especially harrowing, with the crew experiencing exhaustion, and one lapsing into a coma. Bednarik (2003) has unequivocally made the point that $H$. sapiens can build and sail rafts to a known destination and with the type of tools available to $H$. erectus, but this does not necessarily imply that H. erectus had the cognitive and co-operative skills (or the impulse) to build a raft and sail into the unknown. At present, Flores is the sole oceanic island with evidence of hominin colonisation prior to Homo sapiens (Table 1 ), suggesting that $H$. erectus was unlikely to have been making watercraft a million years ago, and still less likely to have willingly undertaken sea voyages.

The second possibility is that hominins arrived accidentally on natural rafts of vegetation that had been swept out to sea following a cyclone or tsunami (Smith, 2001; van den Bergh et al., 2008). This suggestion is not implausible: Smith (2001) cites one instance in the $19^{\text {th }}$ century when a natural raft was mistaken for a three-masted ship; after the 2004 tsunami, a pregnant woman who could not swim was rescued after 5 days from a floating sago tree; and a man was saved $160 \mathrm{~km}$ from the 
coast after 8 days at sea (van den Bergh et al., 2008). These are of course the fortunate survivors of the thousands more who were never seen again. After the Krakatoa-induced tsunami of 1883, a report to The Royal Society of London described "hundreds" of bodies on pumice rafts off the African coast, having drifted across the Indian Ocean (Winchester, 2003). Some of the pumice rafts following this eruption were large enough to support large trees - including ones that washed up over 6,500km from Krakatoa (Thornton, 1996).

It is possible to use simple modelling approaches as an additional way to examine these questions. Ruxton and Wilkinson (2012) showed that an island such as Flores could have been colonised successfully (meaning that its population survived at least 500 years and/or reached a size of 500 individuals) as a result of accidental colonisation (by, for example, small groups of humans swept out to sea on natural rafts of vegetation following a tsunami, as suggested by Smith [2001]). Crucially they also showed that the chances of a success for an accidental colonisation event were about $50 \%$ that of a planned colonisation event by a similar sized group with a balanced sex ratio and high proportion of females of breeding age. Unsurprisingly, success was much greater if the initial unplanned colonisation event was followed by other colonisation events, even if there was only a $2 \%$ chance of a new arrival (involving between 1 and 4 individuals) in any single year. (However, as suggested below, population depletion through natural disasters (such as tsunamis) has to be considered as well as likely rates of immigration). Based on both anecdotal accounts of natural rafting events and these models it seems likely that rafting on natural vegetation was the most likely means by which hominins arrived on Flores.

\subsection{Companions}

What of the faunas associated with $\mathrm{H}$. floresiensis? The vertebrate fauna of Flores was undoubtedly impoverished, with only a dwarf stegodon (Stegodon sondaari), the Komodo dragon (Varanus komodoensis) and a giant tortoise (variously referred to Colossochelys sp. (e.g., Brumm et al., 2010) or Geochelone sp. (e.g., Meijer et al., 2010)) known from Tangi Talo (dating to 0.9 Ma) (Meijer et al., 2010; Brumm et al., 2010). All these taxa are commonly found on islands. Stegodon spp. have a wide and well-known distribution throughout many Southeast Asian islands including Java, Sulawesi, Timor, the Philippines, Mindanao and Sangihe (van den Bergh et al., 1996; van den Bergh, 1999). The Komodo dragon has a somewhat more limited distribution in the islands of the region, with fossils recorded in the Kedung Brubus fauna in Java, as well as Flores. Previous records of the Komodo dragon in Timor (Hooijer, 1972) have recently been interpreted as a new species of Varanus (Hocknull et al., 2009). Varanus komodoensis fossils are found in the Plio-Pleistocene of Australia 
suggesting a possible origin for it there (Hocknull et al., 2009). Colossochelys is known from the Miocene of the Siwaliks and Thailand (Chaimanee et al., 2007). Stegodons, Komodo dragons and tortoises are well known island dispersers, having the ability to either swim or float between islands (Johnson, 1980; Sondaar, 1987, Lutz and Lutz, 1997; Meijer et al., 2010). The exception is the unknown tool-making hominin that was present prior to $1 \mathrm{Ma}$ at the site of Wolo Sege (Brumm et al., 2010), which presumably rafted to get there.

A turnover event was recorded after the Tangi Talo fauna, with a new suite of animals recovered at Mata Menge and similarly aged sites including a new larger species of stegodon (S. florensis), a rat (Hooijeromys nusatenggara), the Komodo dragon and another, once again unknown, tool-making hominin (Meijer et al., 2010). By the time of Homo floresiensis, the rodent taxa may have evolved in situ from H. nusatenggara into two species of the giant rat Papagomys (Locatelli et al., 2012). A species of Spelaeomys (Locatelli et al., 2012), a second species of varanid (Varanus hooijeri) and a giant marabou stork (Leptoptilos robustus) (Meijer and Due, 2010) had also appeared by the late Pleistocene.

\subsection{Route to Flores}

Overall, these appearances and disappearances give the impression of an island fauna in flux, but how does this compare with other islands in the region? In terms of proximity, the nearest islands to the west of Flores are Sumbawa, Lombok, Bali, and Java. Even when sea levels were 120m lower than today, each of these, save for Bali, would have been separated by narrow channels. Homo erectus probably arrived in Sundaland ca. 1.74-1.80 Ma (Bettis et al., 2009) and was in the Sangiran area by $1.51 \mathrm{Ma}$ (Larick et al., 2001), which makes Java the obvious choice for a source population. On the basis of the current geographical distribution the most obvious route to Flores appears to be island hopping from Java-Bali-Lombok-Sumbawa-Flores. A more likely though longer route would be from Cambodia or southern Vietnam through Kalimantan, Sulawesi and thence to Flores. In fact, the idea that a connection between Sulawesi and Flores existed has a long history. It was first proposed in the early $20^{\text {th }}$ century (Sarasin and Sarasin, 1901; Barbour, 1912), and although discounted by Mayr (1944), it was resurrected by Audley-Charles and Hooijer (1973). This latter route is more likely than the former because the prevailing ocean currents flow north-south, from the South China Sea to the Indian Ocean between Kalimantan and Sulawesi, and through the channels between Java, Lombok, Bali and Flores (Morwood and Oosterzee 2007; Morwood and Jungers, 2009). Consequently, accidental rafting from west to east would have been much less likely, and thus a source population for the hominin inhabitants of Flores would probably have been on one of the 
islands to the north, most likely Sulawesi, as suggested by Morwood and Oosterzee (2007), Moorwood and Jungers (2009) and van den Bergh et al. (2008).

Events that might precipitate rafting in Southeast Asia are tsunamis or cyclones. In this case the most likely source populations for Flores would be those living on either side of the Makassar Strait (i.e., eastern Kalimantan or western Sulawesi), as this area is tectonically very active, and has the highest frequency for historical tsunami events in Indonesia, with six recorded since 1900 (Prasetya et al., 2001). From past occurrences, a tsunami $\sim 2 \mathrm{~m}$ high can be expected every 25 years, and a $15 \mathrm{~m}$ tsunami every 100 years (Prasetya et al., 2001). If we accept that hominins arrived on Flores by inadvertent drifting from Sulawesi, equally we should consider that they might have arrived there by drifting from Kalimantan. However, the strengths of tsunamis are diluted off Kalimantan by a shallow off-shore shelf (Prasetya et al., 2001). Western Sulawesi is more adversely affected by tsunamis than eastern Kalimantan-because the latter is buffered, but also because coastal land subsidence accompanies tsunamis and earthquakes offshore from western Sulawesi-making Sulawesi a more likely source for hominins than Kalimantan.

If Sulawesi was the source population for those who were accidentally brought to Flores, other islands could also have been colonised where these conditions prevailed. In present-day Indonesia, these islands could have included Bali, Lombok, Sumbawa, Sumba, Halmahera, Ceram, and Timor. Of these, Halmahera, Ceram, Sumbawa and Timor are larger than Flores (see Table 1). If the size of destination was an important factor (i.e. accidental colonists are less likely to be successful on small islands), Flores might indicate that the colonised island needed to have an area of ca. 5000 sq. $\mathrm{mls} / 14,000 \mathrm{sq} . \mathrm{km}$, and this would exclude smaller islands such as Bali and Lombok.

One not inconsiderable problem with proposing Sulawesi as the best proximate source for the inhabitants of Flores is that there is no clear evidence that hominins were there before $30 \mathrm{ka}$, when H. sapiens arrived (Rabett, 2012). Claims of middle Pleistocene artefacts from Cabenge have not withstood detailed scrutiny, and may be late Pleistocene in age (Bartstra et al., 1991a; Keates and Bartstra, 1994), although the evidence is still inconclusive, as van den Bergh et al. (2001) suggest that some stone artefacts on Sulawesi may be older than previously thought. In a region where so little is known, the possibility that hominins were present on Sulawesi before 40 ka cannot be confidently excluded. A related problem is that there is also no clear evidence that Borneo/Kalimantan was occupied before $45 \mathrm{ka}$, i.e. the earliest evidence from Niah Cave (Barker et al., 2007). To date, Java is the only island in Sundaland with a record of $H$. erectus, although there is 
no a priori reason why it should not also have inhabited suitable areas of the Sunda Shelf, including Sumatra and Kalimantan. In the Philippines, the earliest evidence for hominins is currently ca. $67 \mathrm{ka}$ from Callao Cave (Mijares et al., 2010), which has raised the possibility that $H$. sapiens was already in island South East Asia by this time. To complicate things further, modern humans have been reported from Timor at ca. 42 ka (O'Connor 2007; O'Connor et al., 2010), and archaeological evidence suggests that these populations were sea-faring with advanced maritime skills ( $\mathrm{O}^{\prime}$ Connor et al., 2011). Why modern Homo sapiens bypassed Flores in favour of Timor in the late Pleistocene remains unknown, but the dearth of archaeological excavations in the region may partly explain this apparent pattern (O'Connor, 2007).

\subsection{Biogeographical evidence}

Does the fauna associated with $\mathrm{H}$. floresiensis have any bearing on the point of origin of its population? It is worth noting that the Flores vertebrate fauna is similar to that of the surrounding islands of Lombok, Timor and Sumba (van den Bergh, 1999). Timor, for example, hosted two species of pygmy stegodons, a giant land turtle and a Komodo dragon-sized lizard in the late Pleistocene (Hooijer, 1971; O'Connor 2007). There is no evidence that these species overlapped with Homo sapiens on the island (O'Connor, 2007). In addition to these large-bodied species, Timor also had a number of small and large rodents, bats, lizards and snakes (Hooijer, 1965; Glover, 1986; Aplin and Helgen, 2010), but unlike Flores no records of large ground-dwelling birds have yet been found (O'Connor, 2007).

As noted by Stelbrink et al. (2012) for Sulawesi, during periods of low sea-level islands would have made a larger 'target' for dispersing taxa, making it more likely that sea-route colonisations would occur. Java emerged as an island in the late Pliocene and the earliest (Satir) fauna arrived sometime in the early Pleistocene, probably during periods of low sea level (van den Bergh et al., 2001). Sulawesi has always been completely oceanic and two main routes have been proposed for the arrival of its fauna. The first is the short one from Kalimantan to Sulawesi across a reduced Makassar Strait; the second is longer, and involves a number of crossings from China/Taiwan to the Philippines, and then south to Sulawesi (see van den Bergh et al., 2001). We are therefore left with three potential routes for the hominins' arrival in Wallacea (Figure 2): eastward from Java, eastward from Kalimantan and then south via Sulawesi, or by island hopping from China, the Philippines and Sulawesi. A two-population model for Pleistocene Sundaland - one of $H$. erectus on Java, another of H. floresiensis (or its ancestors) on Kalimantan, Sulawesi and eventually Flores, would avoid the need to explain the absence of any $H$. floresiensis-like hominin in the large Javan sample of $H$. erectus. 
<insert Figure 2 near here>

Sulawesi is east of Wallace's line, but appears to have been colonised multiple times by a wide range of taxa (Stelbrink et al., 2012). In terms of primates, seven species of Macaca are present (Abegg and Thierry, 2002), whose ancestor probably arrived from Borneo (Ziegler et al., 2007), in addition to a number of cryptic tarsier species (Shekelle et al., 2010). Other extant large-bodied mammals include the Sulawesi babyrousa (Babyrousa celebensis), the Sulawesi warty pig (Sus celebensis) (Meijaard et al., 2011) and the anoa (Bubalus depressicornis) (Groves and Leslie, 2011). Java also has a warty pig (Sus verrucosus) and a wild boar (Sus scrofa vittatus) (Meijaard et al., 2011), plus two species of deer - the Javan deer (Cervus timorensis) found on Java and Lombok, probably introduced to other islands (Mattioli, 2011: note though that Heinsohn [2003] considers it to have been transported by people to all islands except Java and Bali), and the red muntjac (Muntiacus muntjak) which is found on a number of the Sunda islands (Mattioli, 2011). The banteng (Bos javanicus) is also present on Java and Borneo (Groves and Leslie, 2011). In terms of mammalian carnivores, the tiger (Panthera tigris) is/was present on Borneo, Java, Palawan and Bali, and the leopard on Java (Wilkinson and O'Regan, 2003; Piper et al., 2008), and Sulawesi has a native palm civet (Macrogalidia musschenbroekii) (Wilson and Mittermeier, 2009).

Overall then, two of the most likely source islands for Flores are well populated by extant largebodied animals, and some important members of the fauna have also become extinct, including the proboscideans Elephas and Stegodon (Louys et al., 2007; Louys, 2008).The oceanic islands to the north and east of Borneo and Sulawesi such as Palawan, the Philippines, and the Moluccas have large-bodied taxa such as pigs (Meijaard et al., 2011), yet the fauna of the southernmost Lesser Sundas (including Lombok, Sumbawa, Flores and Timor) are lacking almost all large-bodied mammals. Possible exceptions to this are the spangled ebony leaf monkey (Trachypithecus auratus) that is found on Lombok and may have naturally dispersed to the island (Abegg and Thierry, 2002) or have been recently introduced from Java (Heinsohn, 2003). Further phylogenetic work on this genus is needed to resolve this question, as the most recent study did not include individuals from Bali or Lombok in their analyses (Roos et al., 2008). The other exception is various species of the extinct genus Stegodon that were found on Flores, Sumbawa and Timor in the Quaternary (van den Bergh, 1999).

A number of possibilities suggest themselves for this pattern. Some animals such as stegodons were clearly excellent colonisers in Southeast Asia. It is possible that once a similar competitor was on the 
island, a small group arriving would struggle to have an impact or displace it (Smith, 2001). This is the argument that has been put forward to explain why the long-tailed macaque Macaca fascicularis did not displace the macaques on Sulawesi, despite colonising many other Southeast Asian islands including the Philippines (Abegg and Thierry, 2002), with an alternative explanation that as many macaque species are inter-fertile, new arrivals might be rapidly assimilated into the existing population (Abegg and Thierry, 2002). In addition, modelling can be used to demonstrate that key aspects of an animals' biology may also relate to its chances of survival - such as the counterintuitive case of the tiger surviving on an island the size of Bali, while the leopard does not (Wilkinson and O'Regan, 2003). With so few fossil sites covering over 1 million years, an arriving species that lasted for only a few tens or hundreds of years would have low chances of being fossilised, and even lower of being found by palaeontologists - they would, in effect, be palaeontologically invisible (O'Regan et al., 2002). (Hominins after 2.6 Ma are usually a notable exception, as they are evidenced far more by their tools than their bones or teeth.) Whatever the case, the island of Flores lacks similarities in terms of mammalian species richness to either of its most likely source islands of Java and Sulawesi.

What of the species that are found in Flores's fossil record? The stegodon S. sondaari is a dwarf species, whose ancestors may have arrived from the Sunda Shelf (van den Bergh, 1999). The later Stegodon florensis was originally described as a subspecies of $S$. trigonocephalus, a Javan stegodon from the early to middle Pleistocene of Java (Hooijer, 1957), but was given full specific distinction by van den Bergh (1999), and may be most closely related to Stegodon species B from Sulawesi (van den Bergh, 1999). Colossochelys is a widespread genus in Asia, with early records from the Siwaliks and Thailand (Chaimanee et al., 2007), as well as Timor (Hooijer, 1971), and Sulawesi (Bartstra, 1977; Bartstra et al., 1991b). There is also a record of a giant tortoise in the Satir fauna of Java (van den Bergh et al., 2001). The giant crane Leptoptilos robustus most closely resembles the greater adjutant (Leptoptilos dubius), a crane currently known throughout Indochina and India, and with a fossil record extending south into Trinil, Java (Meijer and Due, 2010). The Komodo dragon is today found on Komodo, Flores and the smaller islands in between although its fossil record suggests an Australian Pliocene origin with dispersal into the greater and lesser Sundas sometime in the early Pleistocene (Hocknull et al., 2009). Varanus hooijeri is thought to be related to the Nile monitor (V. niloticus) or Gray's monitor (Varanus olivaceus), species from Africa and the Philippines respectively (Molnar, 2004). There are also records of Varanus from Trinil (Molnar, 2004). Hooijeromys, Komodomys and Floresomys are perhaps most closely related to the Sulawesian Eropeplus and 
Lenomys, while Spelaeomys has its closest relatives in Australia and New Guinea via Timor (Musser, 1981).

These fossil taxa therefore suggest a complicated picture of colonisation. Stegodons could equally have arrived from Java and Sulawesi, although a Javan origin is perhaps more probable. Likewise the giant tortoise Colossochelys and the giant crane Leptoptilos robustus could have originated from either island. The Komodo dragon probably came from Sahul while a Sulawesian origin for Varanus hooijeri is hinted at if it is related to Varanus olivaceus. These species are not strictly tied to islands. As discussed, they have great dispersal abilities across water barriers. The same cannot be said for the rodents. Like the Komodo dragon, Spelaeomys may have had a Sahul origin, with movement through Timor and finally to Flores. Other rodents have a suggested Sulawesian origin, and their presence on Flores supports rafting dispersals from the north. Later fossil faunas associated with Homo sapiens are thought to have been transported to Flores artificially (van den Bergh et al., 2009), and their relationships have no real bearing on the origins of Homo floresiensis.

\section{Persistence}

A key question when considering the archaeological record on Flores, is 'how likely is it that a hominin population could survive on a small island for over 1 million years?' Several studies have used modelling approaches to understand the persistence and dynamics of fossil taxa, including moas (Holdaway and Jacomb, 2000), big cats (O'Regan et al. 2002; Wilkinson and O'Regan, 2003) and most recently the thylacine (Prowse et al., 2013). However, such models, termed 'population viability analyses' all require detailed life-history information to be known or to be inferred for the species in question. Homo florensiensis is a very unusual hominin and little is yet known of its biology. Therefore we have not taken this approach here, but rather have looked at three issues that can be examined with current evidence - dwarfing, faunal turnover, and basic energetics.

\subsection{Dwarfing}

The first known fauna from Tangi Talo allows us to consider the role of predation and dwarfing on the island, prior to a possibly volcanically induced extinction event ca. 0.9 Ma (Brumm et al., 2010). Meijer et al. (2010) were careful to emphasise that smaller mammals have not fossilised in the Tangi Talo deposits and that their apparent absence is unlikely to be real. Nonetheless we can focus on the five large vertebrates - three reptiles (Colossochelys sp., Varanus komodoensis and a crocodile) and two mammals (Stegodon sondaari, and presumably a hominin (artefacts are known from Wolo Sege, but there is no associated fauna)). Two factors are commonly said to influence dwarfing on islands - 
food availability and an absence of predators (Meiri et al., 2011). Although the pattern of island dwarfing, and gigantism, across taxa is controversial - there does appear to be 'compelling evidence' for insular dwarfing in larger mammals (Meiri et al., 2011) and $H$. floresiensis has already become a classic textbook example of this (e.g. Cox and Moore, 2010; Mason et al., 2011). It should be noted that some authors consider dwarfing an unlikely explanation for its stature, preferring an evolution from a smaller bodied ancestor such as Homo habilis (Jungers, 2013), but this is not confirmed (Kubo et al., 2013). Here, the question of interest to us is simply the small size of $H$. floresiensis, rather than how it became small. In the case of Flores, predators were present - both primate and reptile, yet Stegodon sondaari is the smallest known dwarf stegodon with an estimated body mass of $\sim 300 \mathrm{~kg}$ (van den Bergh et al., 2008). What do these facts tell us about the conditions on Flores in the early Pleistocene? As the large body size of elephants is regarded as an anti-predation device (i.e., they are too large for most predators to attack them successfully [Sinclair et al., 2003]), the dwarfing of $S$. sondaari on Flores indicates that energetic requirements outweighed the risk of predation, suggesting that the island was somewhat lacking in suitable foodstuffs for them. The dwarfing and hypsodonty demonstrated by the later S. florensis in comparison with mainland stegodons (van den Bergh et al., 2008) also supports this hypothesis. The small stature of $H$. floresiensis also suggests that nutritional requirements outweighed the risks of predation despite co-habiting with a very large lizard that will attack modern Homo sapiens when it gets the chance (McNab, 2012). Thus we may infer that Flores was resource poor for both stegodons and primates, and that the Komodo dragons were not a major threat.

Another key aspect is how rapidly can size reduction occur, and does the presence of a dwarfed animal indicate that a long period must have passed? The indications from a number of taxa are that size reductions can occur quite quickly. For example, last interglacial red deer (Cervus elaphus) on Jersey were reduced to $56 \%$ of the size of their mainland relatives over a period of $6-10,000$ years (Lister, 1995), and the mammoths on Wrangel Island dwarfed within 3-6,000 years (Vartanyan et al., 1993). Changes in size in island rodents have been observed as occurring as quickly as within 150 years when there is competition between similarly sized species (Yom-Tov et al., 1999). Lomolino et al. (in press) also found evidence that recently introduced mammals on islands show a size change, but that the characteristics of insular taxa take longer to develop. A prime example of an insularly adapted mammal is Myotragus balearicus from the Mediterranean - a bovid with ever-growing incisors and shortened distal limb elements - that was present on Mallorca for at least 5 million years (Bover and Alcover, 2003). 


\subsection{Turnover or continuity?}

A further factor in population persistence is natural disasters - so called 'environmental stochasticity' that is widely discussed in the conservation biology literature as an extinction risk, especially for small populations (e.g., Caughley 1994; Simberloff, 1998; Hambler and Canney, 2013). As well as cyclones, Flores sits within a tectonically highly active region with earthquakes, tsunamis and volcanic eruptions a frequent hazard. Flores itself has a 4 Ma record of volcanic activity (Muraoka et al., 2002), with at least 12 active or recently active volcanoes (Stolz et al., 1990). It has been suggested that both $\mathrm{H}$. floresiensis and stegodons may have become extinct following a volcanic eruption ca. $12 \mathrm{ka}$ (Westaway et al., 2007). Tsunamis can also have lethal consequences on Flores, but are obviously a greater risk on smaller islands. For example, in 1992, 1000 people on Flores were killed by an earthquake-induced tsunami (up to $25 \mathrm{~m}$ high), and two thirds of the inhabitants of nearby Babi Island were swept out to sea (Yeh et al., 1993, 1994). Here, the tsunami was especially lethal because it swept around both sides of the island and then converged, sweeping inland. However, because of the size and elevation of Flores, a tsunami is much less likely to affect an entire population than a volcanic eruption that could blanket the entire island.

Ideally, population depletion through natural events such as tsunamis, cyclones and volcanic eruptions ought to be factored into any modelling of whether Flores could have been continuously occupied over a million years. This is of course impractical as their frequency and magnitude are difficult to discern accurately, but it would seem reasonable to suggest that Flores is not an island where one would expect populations to remain unaffected by natural disasters: these types of catastrophes may be very important ecological factors on such islands (Whittaker, 1995). Put another way, one would expect some evidence for faunal discontinuity on an island as exposed to environmental disruption as Flores.

There is indeed a faunal turnover event between the Tangi Talo deposits and those of the slightly later Mata Menge, Boa Lesa and Kobatuwa localities (Meijer et al., 2010). Artefacts are found at all three later deposits, again with a sparse fauna, but the giant tortoise is absent, and a larger (though still dwarfed compared to mainland forms) stegodon S. florensis has taken the place of the older $S$. sondaari, and a rat is also present. The only taxon that appears to have crossed this turnover boundary is the Komodo dragon. Why did the tortoise become extinct? They have very low metabolic rates (a field energy expenditure of approximately $3 \%$ of a similarly sized herbivorous mammal [McNab, 2012]) and might be expected to survive a volcanic event better than many animals (e.g., the many successful tortoise species of the Galapagos Islands). If the Komodo dragon was adapted for eating dwarf stegodon (Diamond, 1987) its extinction may have led it to predate on 
the other available taxa - and tortoise eggs and hatchlings would be vulnerable, even if the adults were not. Interestingly, Komodo dragon teeth were found within the carcass of a giant tortoise at Mata Menge, indicating some sort of interaction between them (van den Bergh, 1999: 359). Such hypothetical prey switching behaviour by Komodo dragons also has implications for potential predation on $\mathrm{H}$. floresiensis.

Meijer et al. (2010) suggest that the Liang Bua fauna exhibits continuity with this earlier Mata Menge fauna, indicating evolution in situ on the island for some $\sim 0.8 \mathrm{Ma}$. The artefacts from Wolo Sege are said to be similar in form to those of Mata Menge (Brumm et al., 2010), while those of Liang Bua are said to exhibit continuity with those of Mata Menge (Brumm et al., 2006). If these tools are similar over $1 \mathrm{Ma}$ period, this provides the best evidence so far for continuity of the hominin populations, although we do need to take into account the profound continuity in early Palaeolithic lithic traditions, and the very slow rate of artefactual change. Some authors have expressed scepticism or astonishment that such small brained hominins could have created stone tools, e.g. 'In the Lesser Sunda archipelago east of Java lived the strange miniature "hobbits", Homo floresiensis. They had brains not much larger than those of chimpanzees yet developed stone tools' (Wilson, 2012: 15), but it should be pointed out that large numbers of animals are tool users - creating nests, webs and traps as well as artefacts (Hansell and Ruxton, 2007). That the use of stones for resource procurement can be innovated independently in the wild is seen in the tool using of capuchins from Brazil (Fragaszy et al., 2004), long-tailed macaques from Thailand (Malaivijitnond et al., 2007; Gumert and Malaivijitnond, 2012) and chimpanzees from West Africa (Boesch and Boesch, 1990; Mercader et al., 2002), in addition to sea otters (Hall and Schaller, 1964) and vultures (Thouless et al., 1989). While the development of a knapped stone tool technology is unlikely to have been independently developed by $\mathrm{H}$. floresiensis, it is certainly possible that such tool-making might be conserved, even during brain reduction, as it is an important part of resource procurement for hominins from 2.6 Ma onwards (Semaw et al., 2003). The immense conservatism of early Palaeolithic stone tool assemblages indicates that the maintenance of an existing tradition is far more deeply-rooted than the ability to innovate - as shown by the continuity in hand-axe forms over the thousands of millennia of the Acheulean. In this light, the long-term maintenance of a simple lithic tradition by a hominin with a chimpanzee-sized brain is less surprising.

\subsection{Energetic considerations}

If the similarity of tool types is an indication of long-term continuity of populations on Flores, are there any biological implications for this? While basic models such as that of Ruxton and Wilkinson 
(2012) indicate that hominins could survive, there were no genetics involved in these calculations. It is known that introducing inbreeding depression into population viability models greatly reduces the chances of survival of the population (e.g. O'Regan et al., 2002; Wilkinson and O'Regan, 2003), but an unplanned and accidental colonisation may result in a genetically more diverse starting population than that found in a planned group so reducing these problems (Ruxton and Wilkinson, 2012). It is clear that over time dwarfing would result in more small individuals being able to exploit the same resource as a few large individuals. This can be illustrated by a basic energetic model for $H$. floresiensis: McNab (2012) gives a generalized eutherian mammalian (i.e. excluding marsupial data) relationship between Field energy expenditure (FEE) and body mass as:

$\mathrm{FEE}(\mathrm{kJ} / \mathrm{d})=4.21 \mathrm{~m}^{0.77}$ where $\mathrm{m}=$ body mass in grams.

FEE is a measure of energy as actually used living in the wild and is higher than basal metabolic rate (BMR) - the usual lab measure of energy use. In mammals FEE is approx 3 times BMR (McNab, 2012).

Brown et al. (2004) give body weight estimates of between $16 \mathrm{~kg}$ to $36 \mathrm{~kg}$ for the $H$. floresiensis LB1. As this specimen has been considered female then a weight of $50 \mathrm{~kg}$ seems reasonable for a likely non-dwarfed ancestor (as $51 \mathrm{~kg}$ for $\mathrm{H}$. erectus female and $54 \mathrm{~kg}$ for $\mathrm{H}$. sapiens female have been used in previous physiological ecology models of human evolution [Ruxton and Wilkinson, 2011]). Using these body masses and the above equation, we can estimate that the field energy expenditure of a $16 \mathrm{~kg} \mathrm{H}$. floresiensis would be $=7269 \mathrm{~kJ} / \mathrm{d}$, for one of $36 \mathrm{~kg}$ it would be $13571 \mathrm{~kJ} / \mathrm{d}$ while for the $50 \mathrm{~kg}$ 'ancestor' it would be $17478 \mathrm{~kJ} / \mathrm{d}$.

Therefore, an adult $H$. floresiensis with a low estimate body mass would use 2.3 times less energy per day than its 'ancestor' while for the large body mass estimate it would be 1.3 times less energy. Taking the midpoint, as a very rough estimate, twice as many individuals of $H$. floresiensis could fit on Flores in comparison with full-sized hominins. This comparison is still valid, whether $H$. floresiensis is dwarfed, or simply from an earlier, smaller-bodied lineage. This simple model goes beyond the intuitively obvious point that a smaller animal needs less energy, and suggests a (very) approximate rate of $50 \%$ less expenditure in $H$. floresiensis compared with a hominin of the size of $H$. erectus. It also illustrates another point - to make any more detailed or realistic quantitative estimates of this type would require much more detailed understanding of the palaeobiology of $H$. floresiensis than is currently the case.

\section{Conclusions}


As we indicated at the start about this paper, discussion about the evidence from Flores has been largely dominated by considerations of the skeletal characteristics of $H$. floresiensis in order to establish its phylogenetic origins, and by speculation as to how it arrived on Flores. While the jury is still divided over whether $H$. floresiensis is a dwarfed version of $H$. sapiens, $H$. erectus or descended from an earlier and more primitive lineage, the consensus opinion is that it arrived on Flores by accidental drifting rather than from purposeful navigation. When viewed from a biogeographical perspective, Flores raises additional substantial problems that cannot at present be answered, but which deserve further exploration. If, as suggested, H. floresiensis arrived from Sulawesi rather than from Java because of the direction of the sea currents, the biogeographical implications are considerable: how, and from where, did it reach Sulawesi, for which currently no evidence that hominins were before $40 \mathrm{ka}$, and which is (like Flores) separated from the Sunda Shelf by a deep sea channel? Why also did it not colonise any of the other islands situated near Flores, where the earliest evidence for any hominin (Homo sapiens) appears to be ca. $42 \mathrm{ka}$ ?

The faunal record of Flores suggests a more complicated colonisation procedure than has previously been credited, with evidence for island hopping taxa from Java, Timor and Sulawesi at various points during the early to middle Pleistocene. Nevertheless, rodents, the only species recorded which would have to have relied on rafting for travel between islands, appear to have both Sahulian and Sulawesian origins. As a Sahulian origin for H. floresiensis can be reasonably discounted at this point, rafting from Sulawesi is tentatively supported by the zoogeographic record. As the Plio-Pleistocene Sulawesian faunas themselves appear to have close affinity with relatives from the Siwaliks (Groves, 1976, 2001; Cranbrook, 1981; Musser, 1987; van den Bergh et al., 2001) rather than with Oriental faunas from China, a scenario involving a migration from South Asia, through Indochina, Sulawesi and thence Flores can be envisaged.

Flores also brings into sharp focus the issue of whether a dated sequence of artefacts (and other kinds of evidence) represents continuous or episodic occupation; in other words, do the gaps indicate an absence of hominins making artefacts, or an absence of artefacts in observed sequences? (see Dennell, 2003). In many respects, Flores is one of the last places where one would expect to find continuous occupation, given that it is volcanically highly active, and lies in a region frequently afflicted by earthquakes, tsunamis and cyclones. This factor is relevant to whether the dwarfing and gigantism in the fauna of Flores resulted from long-term isolation over a million years among a continuous population, or happened over shorter periods following repeated recolonisation on an island that was repeatedly depopulated - the evidence from the stegodons 
would suggest the latter. At present, Flores raises far more questions than can be satisfactorily answered.

\section{Acknowledgements}

The ideas underlying this paper were first discussed by one of the authors (RD) and Alan Turner, with the hope of involving him and his Liverpool colleagues (HO'R, JL, DW). Sadly, his untimely death prevented him from participating. This paper is thus both a paper about Flores, and a collective tribute from his colleagues and friends to a much-valued and much-missed colleague. We also thank Graeme Ruxton for discussions and collaboration on related modelling work on hominin rafting and Leslie Aiello and Colin Groves for useful reviews of an earlier version of this manuscript.

\section{References}

Abegg, C., Thierry, B., 2002. Macaque evolution and dispersal in insular south-east Asia. Biological Journal of the Linnean Society 75, 555-576.

Aiello, L., 2010. Five years of Homo floresiensis. American Journal of Physical Anthropology 142, 167179.

Allen, J., Gosden, C., White, J.P., 1989. Human Pleistocene adaptations in the tropical island Pacific: recent evidence from New Ireland, a greater Australian outlier. Antiquity 63, 548-561.

Aplin, K. P.,Helgen, K. M., 2010. Quaternary murid rodents of Timor part I: new material of Coryphomys buehleri Schaub, 1937, and description of a second species of the genus. Bulletin of the American Museum of Natural History 341, 1-80.

Argue, D., Donlon, D., Groves, C., Wright, R., 2006. Homo floresiensis: Microcephalic, pygmoid, Australopithecus, or Homo? Journal of Human Evolution 51, 360-374.

Audley-Charles, M.G., Hooijer, D. A., 1973. Relation of Pleistocene migrations of pygmy stegodonts to island arc tectonics in eastern Indonesia. Nature 241, 197-198.

Barbour, T., 1912. Contribution to the zoögeography of the East Indian islands. Memoirs of Comparative Zoology Harvard 44, 1-203.

Barker, G.W.W., Barton, H., Bird, M., Daly, P., Datan, I., Dykes, A., Farr, L., Gilbertson, D., Harrisson, B., Hunt, C., Higham, T., Kealhofer, L., Krigbaum, J., Lewis, H., McLaren, S., Paz, V., Pike, A., Piper, P., Pyatt, B., Rabett, R., Reynolds, T., Rose, J., Rushworth, G., Stephens, G., Stephens, M., Stringer, C., 2007. The 'human revolution' in lowland tropical Southeast Asia: the antiquity and behavior of anatomically modern humans at Niah Cave (Sarawak, Borneo). Journal of Human Evolution 52, 243-261. 
Bartstra, G.-J., Keates, S. G., Basoeki, Kallupa, B., 1991a. On the dispersion of Homo sapiens in eastern Indonesia: the Palaeolithic of south Sulawesi. Current Anthropology 32 (3), 317-321.

Bartstra, G.-J., Hooijer, D.A., Kalluper, M., Akib, A, 1991b. Notes on fossil vertebrates and stone tools from Sulawesi, Indonesia, and the stratigraphy of the northern Walanae depression. Palaeohistoria 33-34, 1-18.

Bartstra, G.-J., 1977. Walanae Formation and Walanae Terraces in the stratigraphy of South Sulawesi (Celebes, Indonesia).Quartär 27, 21-30.

Bednarik, R. G. 1999. Maritime navigation in the Lower and Middle Palaeolithic. Comptes Rendues de l'Academie des Sciences 328, 559-563.

Bednarik, R.G., 2003. Seafaring in the Pleistocene.Cambridge Archaeological Journal 13, 41-66.

Bellwood, P., Nithaminoto, G., Irwin, G., Gunadi, G., Waluyo, Taundirjo, D., 1998. 35,000 years of prehistory in the northern Moluccas. In: Bartstra, G.-J. (Ed.) Bird's Head Approaches: Irian Jaya Studies, a Programme for Interdisciplinary research (Modern Quaternary Research in Southeast Asia 15). Balkema, Rotterdam, pp. 233-275.

Bettis, E.A., Milnius, A.K., Carpenter, S.J., Larick, R., Zaim, Y., Rizal, Y., Ciochon, R.L., Tassier-Surine, S.A., Murray, D., Suminto, SutnikoBronto, 2009. Way out of Africa: Early Pleistocene paleoenvironments inhabited by Homo erectus in Sangiran, Java. Journal of Human Evolution $56,11-24$.

Boesch C., Boesch H., 1990. Tool use and tool making in wild chimpanzees. Folia Primatologica 54 (1-2), 86-99.

Bover, P., Alcover, J.A., 2003. Understanding Late Quaternary extinctions: the case of Myotragus balearicus (Bate, 1909). Journal of Biogeography 30, 771-781.

Broodbank, C., 2006. The origins and early development of Mediterranean maritime activity. Journal of Mediterranean Archaeology 19, 199-230.

Brown, P., Maeda, T., 2009. Liang Bua Homo floresiensis mandibles and mandibular teeth: a contribution to the comparative morphology of a new hominin species. Journal of Human Evolution 57, 571-596.

Brown, P., Sutkina, T., Morwood, M. J., Soejono, R. P., Jatniko, Saptomo, E. W., 2004. A new smallbodied hominin from the Late Pleistocene of Flores, Indonesia. Nature 431, 1055-1061.

Brumm, A., Aziz, F., Bergh, G. D. van den, Morwood, M. J., Moore, M., Kurniawan, I., Hobbs, D. R., Fullagar, R., 2006. Early stone technology on Flores and its implications for Homo floresiensis. Nature 441, 624-628.

Brumm, A., Jensen, G.M., van den Bergh, G.D., Morwood, M.J., Kurniawan, I., Aziz, F., Storey, M., 2010. Hominins on Flores, Indonesia, by one million years ago. Nature 464, 748-752. 
Caughley, G., 1994. Directions in conservation biology. Journal of Animal Ecology 63, 215-244.

Chaimanee, Y., Yamee, C., Tian, P., Jaeger, J.-J., 2007. Diversity of Cenozoic mammals in Thailand: palaeoenvironment and age updated. In: Tantiwanit, W. (ed.), Proceedings of the International Conference on Geology of Thailand (GEOTHAI '07): Towards Sustainable Development and Sufficiency Economy. Department of Mineral Resources, Bangkok, 73-79.

Cox C.B., Moore P.D., 2010. Biogeography, $8^{\text {th }}$ ed. John Wiley and Sons, New Jersey.

Cranbrook, Earl of, 1981. The vertebrate faunas. In: Whitmore, T. C. (ed.) Wallace's Line and Plate Tectonics. Clarendon Press, Oxford, pp. 57-69.

Deraniyagala, S.U, 1992. The Prehistory of Sri Lanka (2 volumes).Department of Archaeological Survey, Government of Sri Lanka, Colombo.

Dennell, R.W., 2003. Dispersal and colonisation, long and short chronologies: how continuous is the Early Pleistocene record for hominids outside East Africa? Journal of Human Evolution 45, 421-440.

Détroit, F., Dizon, E., Falguères, C., Hameau, S., Ronquillo, W., Sémah, F., 2004. Upper Pleistocene Homo sapiens from the Tabon Cave (Palawan, The Philippines): description and dating of new discoveries. Comptes Rendues Palévolution 3, 705-712.

Diamond, J.M., 1987. Did Komodo dragons evolve to eat pygmy elephants? Nature 326, 832.

Falk, D., Hildebrot, C., Smith, K., Morwood, M.J., Sutkina, T., Jatmiko, Wayhu Saptomo, Prior, F., 2009. LB1's virtual endocast, microcephaly, and hominin brain evolution. Journal of Human Evolution 57, 597-607.

Fragaszy, D., Izar, P., Visalberghi, E., Ottoni, E.B., Gomes de Oliveira, M., 2004. Wild capuchin monkeys (Cebus libidinosus) use anvils and stone pounding tools. American Journal of Primatology 64, 359-366.

Glover, I.C., 1986. Archaeology in Eastern Timor, 1966-67. Canberra: Department of Prehistory, Research School of Pacific Studies, Australian National University. Terra Australis 11.

Glover, I., 1981. Leang Burung 2: an Upper Palaeolithic rock shelter in south Sulawesi, Indonesia. Modern Quaternary Research in Southeast Asia 6, 1-38.

Groves, C., Leslie Jr., D.M., 2011. Family Bovidae (hollow-horned ruminants). In: Wilson, D.E., Mittermeier, R.A. (Eds.), Handbook of the Mammals of the World Vol. 2: Hoofed Mammals. Lynx edicions, Barcelona, pp. 444-779.

Groves, C. P., 1976. The origin of the mammalian fauna of Sulawesi (Celebes). Zeitshrift Säugetierkunde 41, 201-216.

Groves, C., 2001. Mammals in Sulawesi: where did they come from and when, and what happened to them when they got there? In: Metcalf, I., Smith, J. M. B., Morwood, M., Davidson, I. 
(Eds.), Faunal and Floral Migrations and Evolution in SE Asia-Australasia. A. A. Balema Publishers, Lisse, pp. 333-342.

Gumert, M.D., Malaivijitnond, S., 2012. Marine prey processed with stone tools by Burmese longtailed macaques (Macaca fascicularis aurea) in intertidal habitats. American Journal of Physical Anthropology 149, 447-457.

Hall, K.R.L., Schaller, G.B., 1964. Tool-using behavior of the California sea otter. Journal of Mammalogy 45, 287-298.

Hambler, C., Canney, S., 2013. Conservation. $2^{\text {nd }}$ ed. Cambridge University Press, Cambridge. Hansell, M., Ruxton, G.D., 2007. Setting tool use within the context of animal construction behaviour. Trends in Ecology and Evolution 2007, 73-78.

Heinsohn, T., 2003. Animal translocation: long-term human influences on the vertebrate zoogeography of Australasia (natural dispersal versus ethnophoresy). Australian Zoologist 32, 351-376.

Hershkovitz, I., Kornreich, L., Laron, Z., 2007. Comparative skeletal features between Homo floresiensis and patients with primary growth hormone insensitivity (Laron Syndrome). American Journal of Physical Anthropology 134, 198-208.

Hocknull, S. A., Piper, P.J., van den Bergh, G.D., Due, R.A., Morwood, M.J., Kurniawan, I., 2009. Dragon's paradise lost: palaeobiogeography, evolution and extinction of the largest-ever terrestrial lizards (Varanidae). PLoS ONE 4(9):e7241. doi:10.1371/journal.pone.0007241.

Holdaway, R.N., Jacomb, C. 2000. Rapid extinction of the Moas (Aves: Dinornithiformes): model, test and implications. Science 287: 2250-2254.

Hooijer, D.A., 1957. A Stegodon from Flores. Treubia 24, 119-129.

Hooijer, D.A., 1965. Note on Coryphomys buhleri Schaub, a gigantic murine rodent from Timor. Israel Journal of Zoology 14, 128-133.

Hooijer, D. A., 1971. A giant land tortoise, Geochelone atlas (Flaconer and Cautley) from the Pleistocene of Timor. Proceedings of the Koninklijke Nederlandse Akademie van Wetanschappen Amsterdam B 75, 12-33.

Hooijer D., 1972. Varanus (Reptilia, Sauria) from the Pleistocene of Timor. Zoologische Mededelingen 47, 445-447.

Jacob, T., Indriati, E., Soejono, R.P., Hsu, K., Frayer, D.W., Eckhardt, R.B., Kuperavage, A.J., Thorne, A., Henneberg, M., 2006. Pygmoid Australomelanesian Homo sapiens skeletal remains from Liang Bua, Flores: Population affinities and pathological abnormalities. Proceedings of the National Academy of Sciences USA103, 13421-13426. 
Johnson, D.L., 1980. Problems in the land vertebrate zoogeography of certain islands and the swimming powers of elephants. Journal of Biogeography 7, 383-398.

Jungers, W.L., 2013. Homo floresiensis. In: Begun, D.R. (ed.) A Companion to Paleoanthropology. Wiley-Blackwell, Chichester, pp. 582-598.

Jungers, W.L., Larson, S.G., Harcourt-Smith, W., Morwood, M.J., Sutkina, T., Rokhus Due Awe, Djubianto, T., 2009. Descriptions of the lower limb skeleton of Homo floresiensis. Journal of Human Evolution 57, 548-554.

Kaifu, Y., Fujita, M., 2012. Fossil record of early modern humans in East Asia. Quaternary International 248, 2-11.

Keates, S., Bartstra, G.J. 1994. Island migration of early modern Homo sapiens in Southeast Asia: the artefacts from the Walanae Depression, Sulawesi, Indonesia. Palaeohistoria 33/34, 19-30.

Kubo, D., Kono, R.T., Kaifu, Y., 2013. Brain size of Homo floresiensis and its evolutionary implications. Transactions of the Philosophical Proceedings of the Royal Society of London B 280. http://dx.doi.org/10.1098/rspb.2013.0338.

Larick R., Ciochon, R.L., Zaim, Y., Suminto, S., Izal, Y., Aziz, F., Reagan, M., Heizler, M., 2001. Early Pleistocene ${ }^{40} \mathrm{Ar} /{ }^{39} \mathrm{Ar}$ ages for Bapang Formation hominins, Central Java, Indonesia. Proceedings of the National Academy of Sciences USA 98 (9), 4866-4871.

Larsson, S.G., Jungers, W.L., Tocheri, M.W., Orr, C.M., Morwood, M.J., Sutkina, T., Rokhus Due Awe, Djubiantono, T., 2009. Descriptions of the upper limb skeleton of Homo floresiensis. Journal of Human Evolution 57, 555-570.

Locatelli, E., Awe Due, R., van den Bergh, G.D., van den HoekOstende, L.W., 2012. Pleistocene survivors and Holocene extinctions: the giant rats from Liang Bua (Flores, Indonesia). Quaternary International 281, 47-57.

Lister A.M., 1995. Sea-levels and the evolution of island endemics: the dwarf red deer of Jersey. In: Preece R.C. (ed.), Island Britain: a Quaternary perspective. Geological Society Special Publication No. 96, 151-172.

Lomolino, M.V., van der Geer, A.A., Lyras, G.A., Palombo, M.R., Sax, D.F., Rozzi, R., in press. Of mice and mammoths: generality and antiquity of the island rule. Journal of Biogeography.

Louys, J., 2008. Quaternary extinctions in Southeast Asia. In Elewa AMT (ed.) Mass Extinction. Springer-Verlag, Heidelberg, Germany, pp. 159-189.

Louys, J., Curnoe, D., Tong, H., 2007. Characteristics of Pleistocene megafauna extinctions in Southeast Asia. Palaeogeography, Palaeoclimatology, Palaeoecology243: 152-173.

Lutz, D., Lutz, J.M. 1997. Komodo: The Living Dragon. Dimi Press, Salem (Oregon). 
MacPhee, R.D.E., Burney, D.A. 1991. Dating of modified femora of extinct dwarf Hippopotamus from Southern Madagascar: Implications for constraining human colonization and vertebrate extinction events. Journal of Archaeological Science 18, 695-706.

Malaivijitnond, S., Lekprayoon, C., Tandavanittj, N., Panha, S., Cheewatham, C., Hamada, Y., 2007. Stone-tool usage by Thai long-tailed macaques (Macaca fascicularis). American Journal of Primatology 69, 227-233.

Mason K.A., Losos J.B., Singer S.R., 2011. Biology 9th ed. McGraw Hill, New York.

Matiolli, S., 2011. Family Cervidae (deer). In: Wilson, D.E., Mittermeier, R.A. (Eds.),Handbook of the Mammals of the World Vol. 2: Hoofed Mammals. Lynx edicions, Barcelona, pp. 350-443.

Mayr, E., 1944. The birds of Timor and Sumba. Bulletin of the American Museum of Natural History 83, 123-194.

McNab B.K., 2012. Extreme measures; the ecological energetic of birds and mammals. University Chicago Press, Chicago.

Meijaard, E., d'Huart, J.P., Oliver, W.L.R., 2011. Family Suidae (pigs). In: Wilson, D.E., Mittermeier, R.A. (Eds.),Handbook of the Mammals of the World Vol. 2: Hoofed Mammals. Lynx edicions, Barcelona, pp. 248-291.

Meijer, H.J.M., van den HoekOstende, L.W., van den Bergh, G.D., de Vos, J., 2010. The fellowship of the Hobbit: the fauna surrounding Homo floresiensis. Journal of Biogeography 37, 995-1006.

Meijer, H. J. M., Due, R. A. 2010. A new species of giant marabou stork (Aves: Ciconiiformes) from the Pleistocene of Liang Bua, Flores (Indonesia). Zoological Journal of the Linnean Society $160,707-724$.

Meiri S., Raia P., Phillimore A.B., 2011. Slaying dragons: limited evidence for unusual body size evolution on islands. Journal of Biogeography 38, 89-100.

Mercader, J., Panger, M., Boesch, C., 2002. Excavation of a chimpanzee stone tool site in the African rainforest. Science 296, 1452-1455.

Mijares, A.S., Détriot, F., Piper, P., Grün, R., Bellwood, P., Aubert, M., Champion, G., Cuevas, N., De Leon, A., Dizon, E., 2010. New evidence for a 67,000-year-old human presence at Callao Cave, Luzon, Philippines. Journal of Human Evolution 59, 123-132.

Molnar, R. E., 2004. Dragons in the Dust: The paleobiology of the giant monitor lizard Megalania. Indiana University Press, Bloomington.

Moore, M.W., Sutkina, T., Jatmiko, Morwood, M.J., Brumm, A., 2009. Continuities in stone flaking technology at Liang Bua, Flores, Indonesia. Journal of Human Evolution 57, 503-526. 
Morwood, M.J., 2001. Early hominid occupation of Flores, East Indonesia, and its wider significance. In: Metcalf, I., Smith, J., Davidson, I., Morwood, M.J. (Eds.), Faunal and Floral Migrations and Evolution in SE Asia-Australasia. Swets and Zeitlinger, The Netherlands, pp. 387-398.

Morwood, M.J., Jungers, W.L., 2009. Conclusions: implications of the Liang Bua excavations for hominin evolution and biogeography. Journal of Human Evolution 57, 640-648.

Morwood, M., Oosterzee, P. van, 2007. The Discovery of the Hobbit. Random House Australia, Sydney.

Morwood, M. J., O'Sullivan, P. B., Aziz, F., Raza, A., 1998. Fission-track ages of stone tools and fossils on the east Indonesian island of Flores. Nature 392, 173-176.

Morwood, M. J., Soejono, R. P., Roberts, R. G., Sutnika, T., Turney, C. S. M., Westaway, K. E., Rink, W. J., Zhao, J.-X., van den Bergh, G. D., Due, R. A., Hobbs, D. R., Moore, M. W., Bird, M. I., Fifield, L. K., 2004. Archaeology and age of a new hominin from Flores in eastern Indonesia. Nature $431,1087-1091$.

Muraoka, H., Nasution, A., Urai, M., Takahashi, M., Takashima, I., Simanjuntak, J., Sundhoro, H., Aswin, D., Nanlohy, F., Sitorus, K., Takahashi, H., Koseki, T., 2002.Tectonic, volcanic and stratigraphic geology of the Bajawa geothermal field, central Flores, Indonesia. Bulletin of the Geological Survey of Japan 53, 109-138.

Musser, G.G., 1981.The giant rat of Flores and its relatives east of Borneo and Bali. Bulletin of the American Museum of Natural History 169, 67-176.

Musser, G. G., 1987. The mammals of Sulawesi. In: Whitmore, T. C. (Ed.), Biogeographical Evolution of the Malay Archipelago. Clarendon Press, Oxford, pp. 73-93.

O'Connell, J.F., Allen, J., 2004. Dating the colonization of Sahul (Pleistocene Australia-New Guinea): a review of recent research. Journal of Archaeological Science 31, 835-853.

O'Connor, S., 2007. New evidence from East Timor contributes to our understanding of earliest modern human colonisation east of the Sunda Shelf. Antiquity 81, 523-535.

O'Connor, S., Barham, A., Spriggs, M. et al., 2010. Cave archaeology and sampling issues in the Tropics; A case study from Lene Hara Cave, a 42,000 year old occupation site in East Timor, Island Southeast Asia. Australian Archaeology 71, 29-40.

O'Connor, S., Ono, R. Clarkson, C., 2011. Pelagic fishing at 42,000 years before the present and the maritime skills of modern humans. Science 334, 1117-1121.

O'Connor, S., Spriggs, M., Veth, P., 2005. On the cultural history of the Aru Islands. In: O'Connor, S., Spriggs, M., Veth, P. (Eds.) The Archaelogy of the Aru Islands, Eastern Australia (Terra Australis 23). Pandanus Press, Canberra, pp. 307-314. 
Ono, A., Sato, H., Tsutsumi, T., Kudo, Y., 2002. Radiocarbon dates and archaeology of the Late Pleistocene in the Japanese islands. Radiocarbon 44, 477-494.

O'Regan, H.J., Turner, A., Wilkinson, D.M., 2002. European Quaternary refugia: a factor in large carnivore extinction? Journal of Quaternary Science 17, 789-795.

O'Sullivan, P. B., Morwood, M., Hobbs, D., Aziz, F., Suminto, Situmorang, M., Raza, A., Maas, R., 2001. Archaeological implications of the geology and chronology of the Soa basin, Flores, Indonesia. Geology29 (7), 607-610.

Pavlides, C., Gosden, C., 1994. 35,000-year-old sites in the rainforests of West New Britain, Papua New Guinea. Antiquity 68, 604-610.

Parfitt, S. A., Ashton, N.M., Lewis, S.G., Abel, R.L., Coope, G.R., Field, M.H., Gale, R., Hoare, P.G., Larkin, N.R., Lewis, M.D., Karloukovski, V., Maher, B.A., Peglar, S.M., Preece, R.C., Whittaker, J.E., Stringer, C.B., 2010. Early Pleistocene human occupation at the edge of the boreal zone in northwest Europe.Nature 466, 229-233.

Perry, G.H., Domini, N.J., 2009. Evolution of the pygmy human phenotype. Trends in Ecology and Evolution 24, 218-225.

Piper, P.J., Ochoa, J., Lewis, H., Paz, V.,Ronquillo, W.P., 2008. The first evidence for the past presence of the tiger (Panthera tigris (L.) on the island of Palawan: Extinction in an island population. Palaeogeography, Palaeoclimatology and Palaeoecology 264, 123-127.

Prasetya, G.S., de Lange, W.P., Healy, T.R., 2001. The Makassar Strait tsunamigenic region. Natural Hazards 24, 295-307.

Prowse, T.A.A., Johnson, C.N., Lacy, R.C., Bradshaw, C.J.A., Pollak, J.P., Watts, M.J., Brook, B.W., 2013. No need for disease: testing extinction hypotheses for the thylacine using multispecies metamodels. Journal of Animal Ecology 82, 355-364.

Rabett, R., 2012. Human adaptation in the Asian Palaeolithic: hominin dispersal and behaviour during the late Quaternary. Cambridge University Press,Cambridge.

Richards, G.D., 2006. Genetic, physiologic and ecogeographic factors contributing to variation in Homo sapiens: Homo floresiensis reconsidered. Journal of Evolutionary Biology 19, 17441766.

Roberts, R.G., Westaway, K.E., Zhao, J.-X., Turney, C.S.M., Bird, M.I., Rink, W.J., Fifield, L.K. 2009. Geochronology of cave deposits at Liang Bua and of adjacent river terraces in the Wae Racang valley, western Flores, Indonesia: a synthesis of age estimates for the type locality of Homo floresiensis. Journal of Human Evolution 57, 484-502. 
Roos, C., Nadler, T., Walter, L., 2008. Mitochondrial phylogeny, taxonomy and biogeography of the silvered langur species group (Trachypithecus cristatus). Molecular Phylogenetics and Evolution 47, 629-636.

Ruxton, G.D., Wilkinson, D.M., 2011. Thermoregulation and endurance running in extinct hominins: Wheeler's models revisited. Journal of Human Evolution 61, 169-175.

Ruxton, G.D., Wilkinson, D.M., 2012. Population trajectories for accidental versus planned colonisation of islands. Journal of Human Evolution 63, 507-511.

Sarasin, P., Sarasin, S., 1901. Materialen zur Naturgeschichte der Insel Celebes. Über die geologische Geschichte der Insel Celebes auf Grund der Thierverbreitung, pp. 1-169, maps, pls. 1-15, Wiesbaden.

Semaw, S., Rogers, M.J., Quade, J., Renne, P.R., Butler, R.F., Dominguez-Rodrigo, M., Stout, D., Hart, W.S., Pickering, T., Simpson, S.W., 2003. 2.6-million-year-old stone tools and associated bones from OGS-6 and OGS-7, Gona, Afar, Ethiopia. Journal of Human Evolution 45, 169-177.

Shekelle, M., Meier, R., Wahyu, I., Wirdateti, Ting, N., 2010. Molecular phylogenetics and chronometrics of Tarsiidae based on 12S mtDNA haplotypes: evidence for Miocene origins of crown tarsiers and numerous species within the Sulawesian clade. International Journal of Primatology 31, 1083-1106.

Simberloff, D., 1998. Small and declining populations. In: Sutherland W.J. (Ed.), Conservation, Science and Action. Blackwell Science, Oxford, pp 116-134.

Sinclair A.R.E., Mduma, S., Brashares J.S., 2003. Patterns of predation in a diverse predator-prey community. Nature 425, 288-290.

Smith, J.M.B., 2001. Did early hominids cross sea gaps on natural rafts? In: Metcalf, I.,Smith, J., Davidson, I., Morwood, M.J. (Eds.), Faunal and Floral Migrations and Evolution in SE AsiaAustralasia. Swets and Zeitlinger, The Netherlands, pp. 409-416.

Sondaar, P.Y., 1987. Pleistocene man and extinctions of island endemics. Mémoires de la Société Géologique de France NS 150, 159-165.

Stelbrink, B., Albrecht, C., Hall, R., von Rintelen, T., 2012. The biogeography of Sulawesi revisited: is there evidence for a vicariant origin of taxa on Wallace's "anomalous island"? Evolution 667, 2252-2271.

Stolz, A.J., Varne, R., Dvies, G.R., Wheller, G.J., Foden, J.D., 1990. Magma source components in an arc-continent collision zone: the Flores-Lembata sector, Sunda arc; Indonesia. Contributions to Mineralogy and Petrology 105, 585-601. 
Strasser, T., Panagopoulou, E., Runnels, C., et al. 2010. Stone Age seafaring in the Mediterranean: evidence from the Plakias region for Lower Palaeolithic and Mesolithic habitation of Crete. Hesperia 79, 145-190.

Summerhayes, G.R., Leavesley, M., Fairbairn, A., Mandui, H., Field, J., Ford, A. and Fullagar, R. 2010. Human adaptation and use of plants in highland New Guinea 49,000-44,000 years ago. Science 330, 78-81.

Thornton I., 1996. Krakatau. Harvard University Press, Cambridge Mass.

Thouless, C.R., Fanshawe, J.H., Bertram, B.C.R., 1989. Egyptian Vultures Neophron percnopterus and Ostrich Struthio camelus eggs: the origins of stone-throwing behaviour. Ibis 131, 9-15.

Tocheri, M.W., Orr, C.M., Larson, S.G., Sutkina, T., Jatmiko, Saptomo, E.W., Rokus Awe Due, Djubianto, T., Morwood, M.J., Jungers, W.L., 2007. The primitive wrist of Homo floresiensis and its implications for hominin evolution. Science 317, 1743-1745.

van den Bergh, G.D.,1999. The Late Neogene elephantoid-bearing faunas of Indonesia and their palaeozoogeographic implications; a study of the terrestrial faunal succession of Sulawesi, Flores and Java, including evidence for early hominid dispersal east of Wallace's Line. Scripta Geologica 117, 1-419.

van den Bergh, G.D., Rokhus Due Awe, Morwood, M.J., Sutikna, T., Jatmiko, WahyuSaptomo, E., 2008. The youngest Stegodon remains in Southeast Asia from the Late Pleistocene archaeological site Liang Bua, Flores, Indonesia. Quaternary International 182, 16-48. van den Bergh, G. D., Sondaar, P. Y., de Vos, J., Aziz, F., 1996. The proboscideans of the South-East Asian islands. In: Tassy, P., Shoshani, J. (Eds.),The Proboscidea: Evolution and Palaeoecology of Elephants and their Relatives. Oxford University Press, Oxford, pp. 240-248.

van den Bergh, G. D., de Vos, J., Sondaar, P. Y., 2001.The Late Quaternary palaeogeography of mammal evolution in the Indonesian Archipelago.Palaeogeography, Palaeoclimatology, Palaeoecology $171,385-408$.

van den Bergh, G.D., Meijer, H.J.M., Rokhus Due Awe, Morwood, M.J., Szabó, K., van den Hoek Ostende, L.W, Sutikna, T., Saptomo, E.W, Piper, P.J., Dobney, K.M., 2009. The Liang Bua faunal remains: a 95 k.yr. sequence from Flores, East Indonesia. Journal of Human Evolution $57,527-537$.

Vartanyan, S.L., Garutt, V.E., Sher, A.V. 1993. Holocene dwarf mammoths from Wrangel Island in the Siberian Arctic. Nature 362, 337-340.

Westaway, K.E., Zhao, J.-X.,Roberts, R.G., Chivas, A.R., Morwood, M.J., Sutkina, T., 2007. Initial speleothem results from western Flores and eastern Java, Indonesia: were climate changes 
from 47 to 5 ka responsible for the extinction of Homo floresiensis? Journal of Quaternary Science 22(5), 429-438.

Whittaker, R.J. 1995. Disturbed island ecology.Trends in Ecology and Evolution 10, 421-425.

Wilkinson, D.M., O'Regan, H.J., 2003. Modelling differential extinctions to understand big cat distribution on Indonesian islands. Global Ecology and Biogeography 12, 519-524.

Wilson, D.E, Mittermeier R.A., eds., 2009. Handbook of Mammals of the World. Vol. 1.Carnivores. Lynx Edicions, Barcelona.

Wilson E.O., 2012. The Social Conquest of Earth. Liveright, New York.

Winchester, S., 2003. Krakatoa. Viking, London.

Yeh, H., Imamura, F., Synolakis, C., Tsuji, Y., Liu, P., Shi, S., 1993. The Flores Island tsunamis. Eos 74 (33), 369, doi: 10.1029/93EO00381.

Yeh, H., Liu, P., Briggs, M., Synolakis, C., 1994. Propagation and amplification of tsunamis at coastal boundaries. Nature 372, 353-355.

Yom-Tov, Y., Yom-Tov, S., Moller, H., 1999. Competition, coexistence, and adaptation amongst rodent invaders to Pacific and New Zealand islands. Journal of Biogeography 26, 947-958.

Ziegler, T., Abegg, C., Meijaard, E., Perwitasari-Farajallah, D., Walter, L., Hodges, J.K., Roos, C., 2007. Molecular phylogeny and evolutionary history of Southeast Asian macaques forming the $M$. silenus group. Molecular Phylogenetics and Evolution 42, 807-816. 


\section{Figure Captions}

Figure 1. Map of Flores, Indonesia, showing archaeological and palaeontological localities mentioned in the text (stars) and key towns (circles) for orientation. Adapted after Brumm et al. (2010).

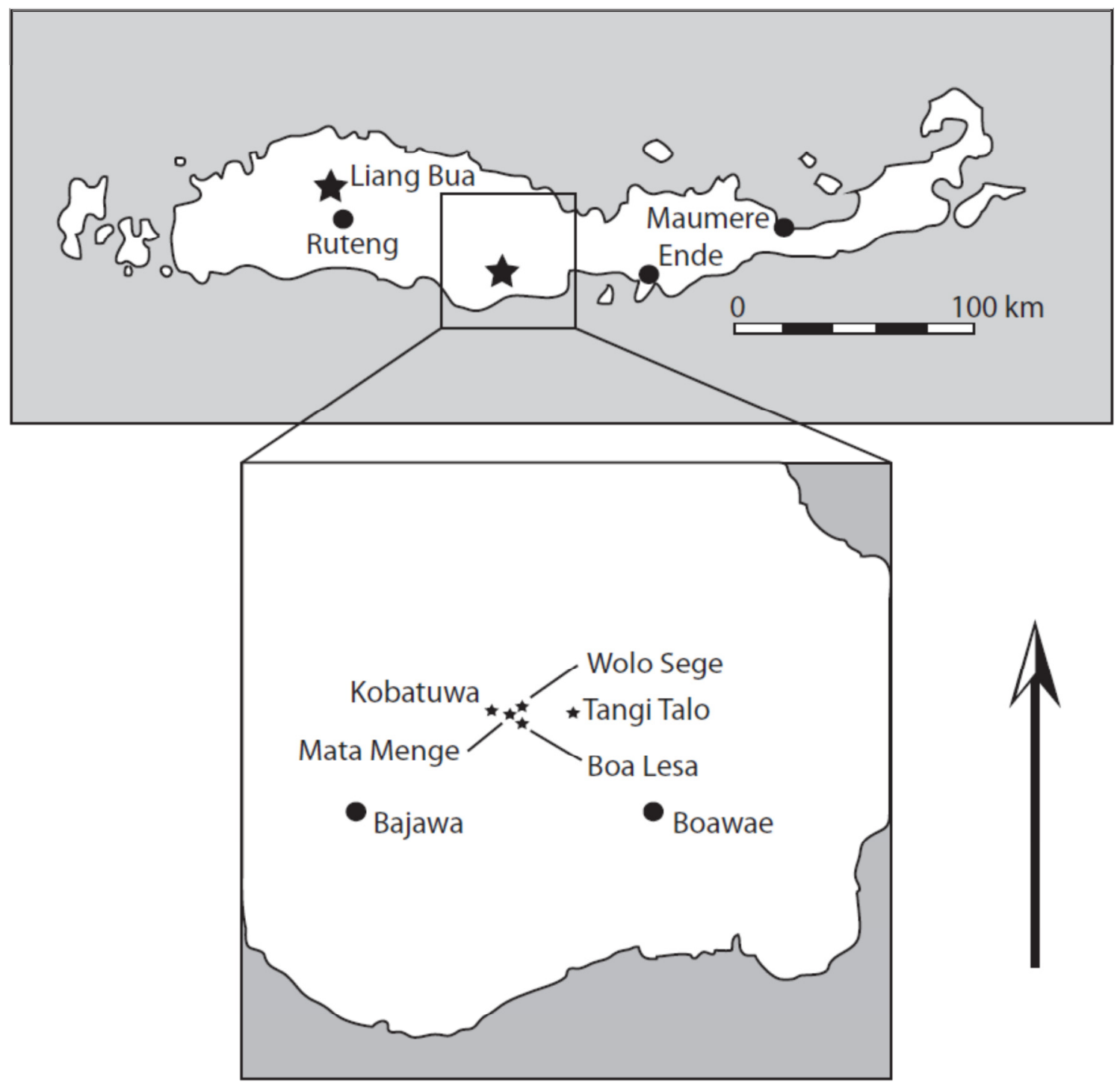


Figure 2. Map of Southeast Asia showing the location of islands discussed in the text, and the three proposed routes of dispersal for taxa arriving on Flores: 1) eastward from Java, 2) from Kalimantan via Sulawesi and 3) from China via the Philippines and Sulawesi.

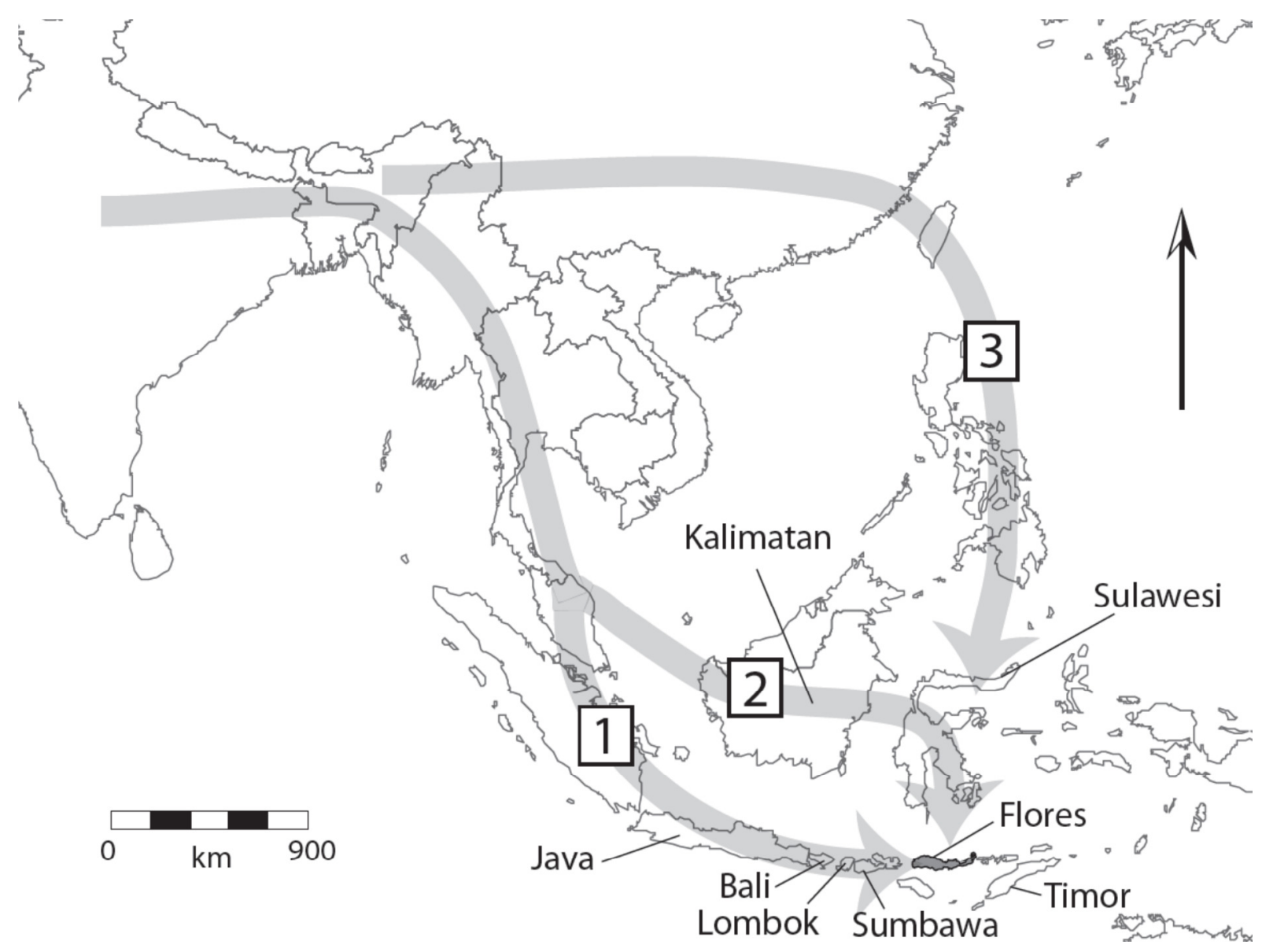


Table 1. Size of islands and current dates for their colonisation (excluding the Americas, the Arctic and Antarctic regions, and New Zealand). Bold indicates that they were still islands when sea levels were 100m lower than today. Sources: Island sizes: Wikipedia and http://www.worldislandinfo.com.

\begin{tabular}{|c|c|c|c|c|c|c|}
\hline $\begin{array}{l}\text { World } \\
\text { Ranking }\end{array}$ & Name & Sq. mls & Sq. km & First date & Source & Comments \\
\hline 2 & New Guinea & 309,000 & 800,000 & $50 \mathrm{ka}$ & $\begin{array}{l}\text { Summerhayes et al., } \\
2010\end{array}$ & Part of Sahul but colonised by sea \\
\hline 3 & Borneo & 280,100 & 725,500 & Ca. $45 \mathrm{ka}$ & Barker et al., 2007 & Joined to Sunda at $-50 \mathrm{~m}$ \\
\hline 4 & Madagascar & 226,658 & 578,041 & $2 \mathrm{ka}$ & $\begin{array}{l}\text { MacPhee and Burney, } \\
1991\end{array}$ & \\
\hline 6 & Sumatra & 164,000 & 425,000 & ? & $\begin{array}{l}\text { Probably colonised same } \\
\text { time as Java }\end{array}$ & Joined to Sunda at $-50 \mathrm{~m}$ \\
\hline 7 & Honshu, Japan & 87,805 & 227,414 & $\begin{array}{l}\text { ca. 30-35 } \\
\text { ka }\end{array}$ & Ono et al., 2002 & $\begin{array}{l}\text { The main Japanese islands would have } \\
\text { merged at }-100 \mathrm{~m} \text { sea levels }\end{array}$ \\
\hline 9 & Britain & 83,896 & 216,777 & Ca. $1 \mathrm{Ma}$ ? & Parfitt et al., 2010 & $\begin{array}{l}\text { Repeatedly joined to mainland Europe when } \\
\text { sea levels low }\end{array}$ \\
\hline 11 & Celebes/Sulawesi & 67,400 & 174,600 & $30 \mathrm{ka}$ & Bellwood et al., 1998 & \\
\hline 13 & Java & 48,900 & 126,700 & $1.5 \mathrm{Ma}$ & Larick et al., 2001 & \\
\hline 17 & Luzon, Philippines & 40,419 & 104,684 & c.67 ka & Mijares et al., 2010 & $\begin{array}{l}\text { Callao Cave, human metatarsal. Main } \\
\text { Philippine islands would have merged at - } \\
\text { 100m sea levels }\end{array}$ \\
\hline 19 & Mindano, Philippines & 36,537 & 94,627 & unknown & & Probably as for Luzon \\
\hline
\end{tabular}




\begin{tabular}{|c|c|c|c|c|c|c|}
\hline 20 & Ireland & 32,589 & 84,406 & $\begin{array}{l}\text { Early } \\
\text { Holocene }\end{array}$ & & Joined to Britain at $-100 m$ sea level \\
\hline 21 & Hokkaido, Japan & 30,144 & 78,073 & $30-35 \mathrm{ka}$ & Ono et al., 2002 & \\
\hline 25 & Sri Lanka & 25,200 & 65,268 & $70 \mathrm{ka}$ & Deraniyagala, 1992 & $\begin{array}{l}\text { Repeatedly joined to India when sea levels } \\
\text { low }\end{array}$ \\
\hline 26 & Tasmania & 23,412 & 60,637 & $40 \mathrm{ka}$ & O'Connell and Allen, 2004 & Joined to mainland when colonised \\
\hline 36 & Kyushu, Japan & 14,114 & 36,555 & $30-35 \mathrm{ka}$ & Ono et al., 2002 & \\
\hline 37 & New Britain & 14,098 & 36,514 & $35 \mathrm{ka}$ & $\begin{array}{l}\text { Pavlides and Gosden, } \\
1994\end{array}$ & \\
\hline 38 & Taiwan & 13,823 & 35,801 & & & $\begin{array}{l}\text { Repeatedly joined to mainland when sea } \\
\text { levels low }\end{array}$ \\
\hline 39 & Hainan & 12,962 & 33,572 & & & $\begin{array}{l}\text { Repeatedly joined to mainland when sea } \\
\text { levels low }\end{array}$ \\
\hline 43 & Timor & 11,883 & 30,777 & 42 ka & O'Connor et al., 2011 & \\
\hline 44 & Sicily & 9,830 & 25,460 & $\begin{array}{l}\text { Probably } \\
\text { Holocene }\end{array}$ & Broodbank, 2006 & \\
\hline 46 & Sardinia & 9,194 & 23,813 & $\begin{array}{l}\text { Early } \\
\text { Holocene }\end{array}$ & Broodbank, 2006 & \\
\hline 48 & Shikoku & 7,251 & 18,780 & $30 \mathrm{ka} ?$ & Ono et al., 2002 & Probably colonised same time as Honshu \\
\hline 49 & $\begin{array}{l}\text { Halmahera, } \\
\text { Indonesia }\end{array}$ & 6,865 & 17,780 & $32 \mathrm{ka}$ & Glover, 1981 & \\
\hline
\end{tabular}




\begin{tabular}{|l|l|l|l|l|l|l|}
\hline 56 & Sumbawa, Indonesia & 5,965 & 15,448 & Not clear & & \\
\hline $\mathbf{5 7}$ & Flores, Indonesia & $\mathbf{5 , 5 2 0}$ & $\mathbf{1 4 , 3 0 0}$ & $\mathbf{1 ~ M a}$ & Brumm et al., 2010 & Island at -100m \\
\hline 61 & Samar, Philippines & 5,050 & 13,079 & $\begin{array}{l}\text { Probably } \\
<30 \text { ka }\end{array}$ & & \\
\hline 64 & Palawan, Philippines & 4,550 & 11,784 & $\begin{array}{l}\text { ca. 30-40 } \\
\text { ka }\end{array}$ & Détroit et al., 2004 & $\begin{array}{l}\text { Tabon Cave; Dating of human remains not } \\
\text { yet prece }\end{array}$ \\
\hline 81 & Cyprus & 3,572 & 9,251 & $\begin{array}{l}\text { Early } \\
\text { Holocene }\end{array}$ & Broodbank, 2006 & \\
\hline 84 & Corsica & 3,351 & 8,681 & $\begin{array}{l}\text { Early } \\
\text { Holocene }\end{array}$ & Broodbank, 2006 & \\
\hline 89 & New Ireland & 3,344 & 8,661 & 35 ka & Allen et al., 1988 & \\
\hline
\end{tabular}

